\title{
The rise of groin injection among opiate drug users in Malaysia
}

\author{
B. Vicknasingam ${ }^{l}$, Suresh Narayanan ${ }^{2}$, Darshan Singh ${ }^{l}$. \\ ${ }^{I}$ Centre for Drug Research, Universiti Sains Malaysia, Penang, Malaysia; \\ ${ }^{2}$ School of Social Sciences, Universiti Sains Malaysia, Penang, Malaysia. \\ Correspondence email: vickna@usm.my, vicknab@hotmail.com
}

\begin{abstract}
Introduction:There have been no previous studies attempting to understand groin injection among opiate drug users in Malaysia. This paper aims to examine if there are characteristics that distinguish groin injectors from other Injecting Drug Users (IDUs) and the reasons for resorting to groin injection.

Methods: From a larger survey of 552 participants, recruited using a convenience sample in five locations around the country, a sub-sample of 64 participants was found to be groin injectors. Participants were screened for $\mathrm{HIV}$ and HCV. Another 20 groin injectors were recruited from Penang using a questionnaire designed specifically to obtain a more in-depth understanding of the groin injection.

Results: Groin and non-groin injectors displayed same high risk behaviours. Groin injectors had a longer history and they were also more likely to be HCV positive. Results also show that injecting from other sites in the body has been hastened to the groin to experience euphoria in the shortest time. Groin injectors also have a high degree of awareness on the dangers of injecting in the groin.

Conclusion: Early intervention is needed to prevent drug users from becoming injectors. For current groin injectors, proper counselling on the dangers of groin injection and vein management is crucial.
\end{abstract}




\section{زيادة نسب التعاطي عن طريق حقن الأربية بين متعاطي الأفيون في ماليزيا}

$$
\text { جامعة ساينز ماليزيا، بامينج و سوريش نار ايانان و دارشان سينج }
$$

الملخص:

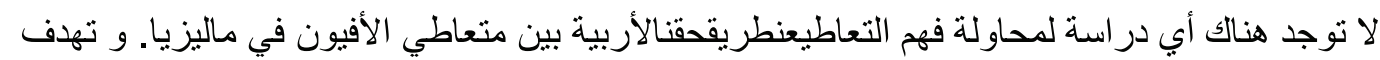

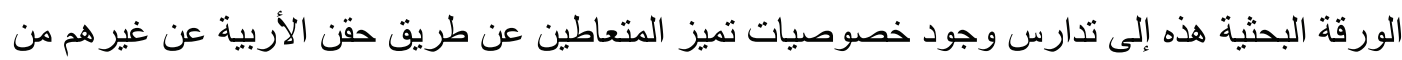
متعاطو المخدرات عبر الحقن و الأسباب التي أدت بهم إلى التعاطي عبر حقن التهن الأربية.

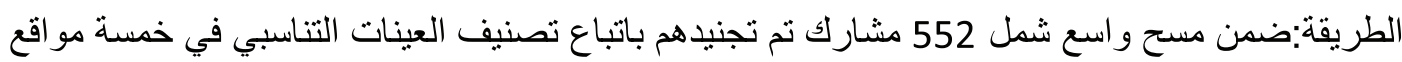

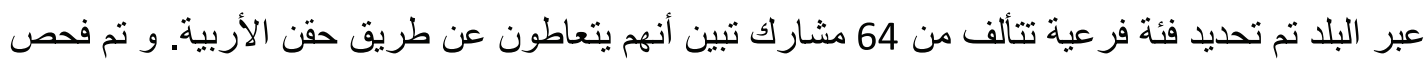

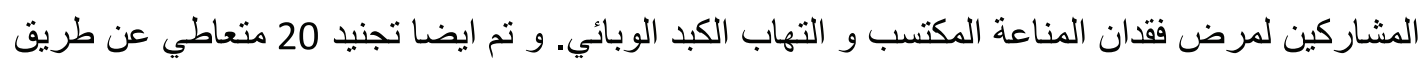

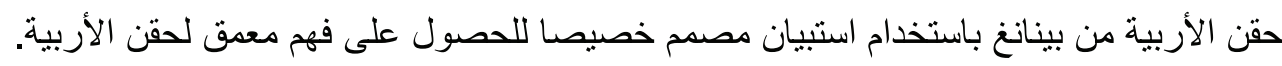

النتائج:أظهركلا من المتعاطين عن طريق حقن الأربية و المتعاطون عن طريق الحقن الآخرين سلوكيات

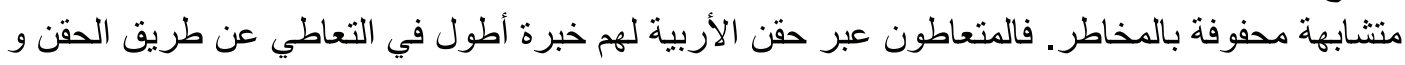

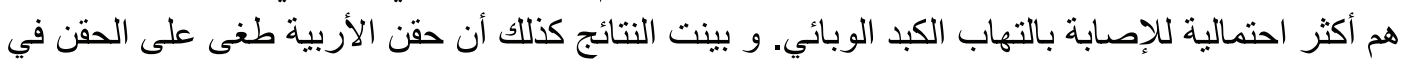

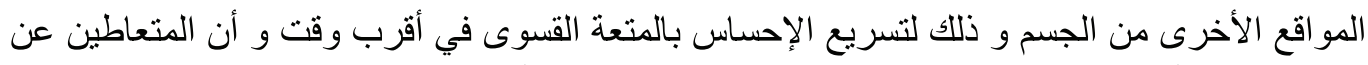
طريق حقن الأربية يدركون تماما المخاطر المترتبة عن حقن الأربية.

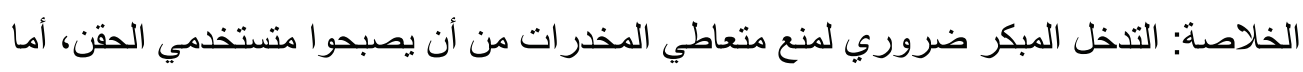

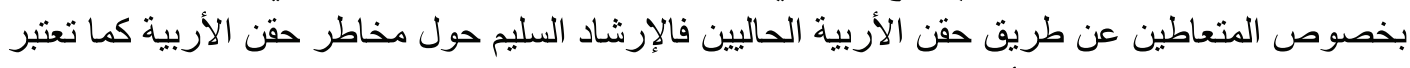
إدارة العروق الدموية بالغة الأهمية.

Keywords: Groin injectors, Injecting drug use, Opiates, IDU

\section{Introduction}

Groin (femoral vein) injecting carries with it a risk beyond that of injecting in other sites including Deep Venous Thrombosis (DVT), accidental arterial injection, venous ulceration and local infections. It was initially seen as a relatively rare phenomenon resorted as a 'last resort' by long-term IDUs who have run out of other viable sites. Rhodes reported the rise of groin injection as a preferred site rather than a last choice. ${ }^{1}$ Apart from a few studies, little is known regarding the incidence of this occurrence elsewhere. ${ }^{2,3,4,5,6,7}$ However, in the UK where its rise has been documented, there is a debate as to how existing harm reduction approaches should handle the special challenges posed in counselling groin injectors. ${ }^{3}$ 
None of the previous studies on drug users in Malaysia have reported the groin injection and little is known regarding its incidence. But in the course of a larger studyaimed at collecting behavioural data with respect to injecting drug users, the first indication about the existence of groin injectors surfaced. ${ }^{8,9}$ It was found that 64 out of the 552 subjects (11.6\%) who participated in the survey were groin injectors-subjects who reported injecting either exclusively in the groin or resorting to the groin, alongside other areas. The details of groin injectors were therefore subjected to a separate analysis and a follow up survey was initiated to better understand the reasons for resorting to groin injection. This paper reports the findings and discusses the implications for harm reduction.

\section{Objectives}

We had two objectives: first, to examine if there are characteristics that distinguish groin injectors from other IDUs; second, to study the reasons for resorting to groin injection. Such information might assist in reducing the associated harm.

\section{Methods}

\section{Data collection procedures}

As part of a larger World Health Organization funded study on IDU, a cross-sectional survey was conducted in five locations across Peninsular Malaysia.

Since drug use is a criminal offence in Malaysia and drug users are a hidden population, it was not possible to get a representative sample through conventional sampling procedures. Instead, convenience sampling was used with the help of key informants-former drug users working with local non-governmental organisations who helped recruit subjects for interviews.

The criteria for inclusion were:

i. Injecting drug use in the last seven days.

ii. Willingness to undergo on-site serological tests for HIV and hepatitis $\mathrm{C}(\mathrm{HCV})$.

iii. Voluntary participation with informed consent, in accordance with the ethical guidelines of the study.

Trained interviewers collected data via face-to-face interviews using a struc- 
tured questionnaire. Information was elicited on socio-demographic details, drug injecting practices, and sexual behaviour. The subjects were assured of complete confidentiality. HIV and HCV screenings were done by the interviewers who were trained to use the rapid test kits (HIV 1/2/0 Tri-line single use rapid test kit, Acon laboratories Inc.). However, confirmation tests were not done. Subjects were told that the tests were only screens and the importance of going for confirmation tests at a hospital was emphasised. They were also provided with information on drug treatment services (not HIV treatment) available near the study locations.

The research protocol was approved by the Research and Ethical Committee (Human Studies) of Universiti Sains Malaysia, Penang.

A total of 552 subjects across the five locations were interviewed: Penang in the north ( $\mathrm{n}=100)$; Kuala Lumpur in the west $(\mathrm{n}=118)$; Johor Bahru in the south $(n=131)$; Kota Baru in the east $(n=104)$ and Kuantan in the centre $(n=$ 99). After 26 non-IDUs were eliminated, 526 subjects remained. Of this, 64 $(12.2 \%)$ were found to be groin injectors. Subsequently, another 20 groin injectors from Penang were interviewed using a specifically designed questionnaire to better understand the groin injecting behaviour of opiate drug users.

\section{Data analysis}

The existence of significant differences between groin injectors and nongroin injectors - with respect to selected variables of interest was first determined via Chi-squared tests. The odds ratio (OR) and related confidence intervals (CI) were computed for variables of significance. The criterion for statistical significance was the two-tailed test at $P<0.05$ in the bivariate analysis. Computations of Chi squared values, OR and CI were done using utilities available at Vassar Stats (http://faculty.vassar.edu/lowry/VassarStats.html).

\section{Results from the overall survey}

\section{Socio-demographic characteristics}

Groin injectors, like all drug users in Malaysia, were predominantly male and came disproportionately from the Malay community (Table 1). They were, on average, older than other injectors; their mean age was 39.3 years $(\mathrm{SD}=7.48)$ relative to the 36.7 years $(\mathrm{SD}=8.08)$ mean age of other injectors. The average level of education ( 9.1 years; $\mathrm{SD}=2.81$ ) was no different from the other injectors. About $67 \%$ were either unemployed or held irregular 
jobs. However, the majority (69\%) reported monthly incomes in excess of RM500 (USD1=RM3.5).

The overall HIV prevalence rate was $40.6 \%$ in the sample while HCV prevalence was even higher at $81.3 \%$.

Table 1. Socio-demographic characteristics of groin and non-groin injectors

\begin{tabular}{|c|c|c|c|c|c|}
\hline & $\begin{array}{l}\text { Groin injec- } \\
\text { tors } \\
\mathbf{n}=\mathbf{6 4}\end{array}$ & $\%$ & $\begin{array}{l}\begin{array}{l}\text { Non-groin } \\
\text { injectors }\end{array} \\
\mathrm{n}=\mathbf{4 6 2}\end{array}$ & $\%$ & p-value \\
\hline \multicolumn{6}{|l|}{ Race } \\
\hline Malay & 41 & & 386 & & 0.000 \\
\hline Non-Malay & 23 & & 76 & & \\
\hline \multicolumn{6}{|l|}{ Gender } \\
\hline Male & 63 & & 438 & & $0.237 *$ \\
\hline Female & 1 & & 24 & & \\
\hline \multicolumn{6}{|l|}{ Age } \\
\hline$\leq 28$ years & 5 & & 75 & & 0.079 \\
\hline$>28$ & 59 & & 387 & & \\
\hline Mean age (years) & $\begin{array}{l}39.3 \\
(\mathrm{SD}=2.81)\end{array}$ & & $\begin{array}{l}36.7 \\
(\mathrm{SD}=8.08)\end{array}$ & & \\
\hline \multicolumn{6}{|l|}{ Education } \\
\hline$\leq 6$ years & 10 & & 58 & & 0.493 \\
\hline$>$ Form 6 & 54 & & 404 & & \\
\hline $\begin{array}{l}\text { Mean education } \\
\text { (years) }\end{array}$ & $9.1(\mathrm{SD}=2.81)$ & & $9.2(\mathrm{SD}=2.5)$ & & \\
\hline \multicolumn{6}{|l|}{ Employment } \\
\hline None/part time & 42 & & 263 & & 0.1858 \\
\hline Full time & 22 & & 199 & & \\
\hline \multicolumn{6}{|l|}{ Income (month) } \\
\hline$\leq \mathrm{RM} 500$ & 20 & & 149 & & 0.862 \\
\hline$>$ RM500 & 44 & & 313 & & \\
\hline
\end{tabular}

Note: Values in bold indicate $p<0.05$.

*Fisher's exact test 


\section{Drug use practices}

In common with all drug users in Malaysia, groin injectors were also using heroin (64\%) with morphine and benzodiazepine being the other widely used drugs (Table 2).

Injecting drug use was initiated at a mean age of 24 years $(\mathrm{SD}=6.34)$ with the average length of injecting drug use being 15.3 years. The sharing of needles and other injecting equipment was common with $70 \%$ reporting sharing of injecting equipment.

Table 2. Drug use and sexual practices of groin and non-groin injectors

\begin{tabular}{|l|l|l|l|l|l|}
\hline & $\begin{array}{l}\text { Groin injec- } \\
\text { tors }\end{array}$ & $\%$ & $\begin{array}{l}\text { Non-groin } \\
\text { injectors }\end{array}$ & \multicolumn{2}{l|}{$\begin{array}{l}\text { p- } \\
\text { value }\end{array}$} \\
\hline Type of Drug & & & & & \\
\hline Heroin & 41 & 64.1 & 286 & 61.9 & 0.740 \\
\hline Morphine \& other & 23 & 35.9 & 176 & 38.1 & \\
\hline Age began injecting & & & & & \\
\hline$\leq 28$ years & 52 & 81.3 & 374 & 81.0 & 1.00 \\
\hline$>28$ & 12 & 18.8 & 88 & 19.0 & \\
\hline Mean age of injection & $24.0(\mathrm{SD}=6.34)$ & - & $24.5(\mathrm{SD}=6.10)$ & - & \\
\hline Mean length of drug use & 15.3 years & - & 12.2 years & - & \\
\hline $\begin{array}{l}\text { Sharing injecting equip- } \\
\text { ment }\end{array}$ & & & & & \\
\hline Yes & 45 & 70.3 & 316 & 68.4 & 0.752 \\
\hline No & 19 & 29.7 & 146 & 31.6 & \\
\hline HIV status & & & & & \\
\hline Positive & 26 & 40.6 & 205 & 44.4 & 0.572 \\
\hline No & 38 & 59.4 & 257 & 55.6 & \\
\hline HCV status & & & & & \\
\hline Positive & 52 & 81.3 & 301 & 65.2 & $\mathbf{0 . 0 1 0}$ \\
\hline No & 12 & 18.7 & 161 & 34.8 & \\
\hline HCV awareness & & & & & \\
\hline Yes & 32 & 50.0 & 161 & 34.8 & $\mathbf{0 . 0 1 8}$ \\
\hline No & 32 & 50.0 & 301 & 65.2 & \\
\hline Sought Physician's advice & & & & & \\
\hline Yes & 37 & 57.8 & 262 & 56.7 & 0.862 \\
\hline & & & & \\
\hline
\end{tabular}




\begin{tabular}{|l|l|l|l|l|l|}
\hline No & 27 & 42.2 & 200 & 43.3 & \\
\hline Sexual orientation & & & & & \\
\hline Homosexual/bisexual & 20 & 31.3 & 141 & 30.5 & 0.920 \\
\hline Heterosexual & 44 & 68.8 & 321 & 69.4 & \\
\hline Sex partners & & & & & \\
\hline Multiple & 41 & 64.1 & 265 & 57.4 & 0.308 \\
\hline Steady/none & 23 & 35.9 & 197 & 42.6 & \\
\hline Condom use & & & & & \\
\hline Never/sometimes & 54 & 84.4 & 356 & 77.1 & 0.186 \\
\hline Always & 10 & 15.6 & 106 & 22.9 & \\
\hline
\end{tabular}

Note: Values in bold indicate $p<0.05$.

\section{Sexual behaviours}

The majority (69\%) was heterosexual but many (64\%) reported engaging in sex with multiple partners. Regular condom use, however, was low with just $16 \%$ reporting consistent use.

\section{Factors associated with groin injection}

Despite the fact that both groups started injecting around the same age (2425 years), not surprisingly, groin injectors had a longer history of injecting drug use (mean $=15.3$ years) relative to non-groin injectors (mean $=12.2$ years). With respect to most other variables, groin injectors were no different from other injecting drug users.

However, the former had higher odds of being $\mathrm{HCV}$ positive $(\mathrm{OR}=2.3$; 95\%CI: 1.20-4.47) as compared to the latter. The former also showed a greater awareness regarding the consequences of $\mathrm{HCV}$ seropositivity $(\mathrm{OR}=1.87$; CI: 1.10-3.16). In our sample, the odds of groin injectors being non-Malays were higher $(\mathrm{OR}=2.73$; $\mathrm{CI}: 1.54-4.84)$, despite the fact that many Malaysian studies have shown that the majority of IDUs is Malay. This is clearly a sample-specific rather than a general characteristic.

\section{Results from the small sample}

\section{Age and length of drug use}

In our sample of 20 groin injectors, the mean age was even higher (41.3 years; $\mathrm{SD}=8.93)$ and all except one $(5 \%)$ were males. Drug use was initiated 
at a mean age of 20.5 years $(\mathrm{SD}=3.67$ and the average drug use history was 20.8 years (measured as the difference between current age and age of first initiation into drug use) and the transition from initiating drug use to becoming a groin injector took an average of 11.7 years.

\section{Length of time injecting}

Drug use was initiated at a mean age of 20.5 years $(\mathrm{SD}=3.67)$ while injecting drug use began at a mean age of $25.7(\mathrm{SD}=6.06)$. Thus, on average, the transition from being a drug user to an injecting drug user took 5.2 years. The mean length of time injecting (in the groin or otherwise) was 15.6 years.

\section{Length of time in groin injecting}

The mean age at which groin injection was initiated was 32.2 years $(\mathrm{SD}=8.56)$ and the average length of transition from injecting to groin injecting was 6.5 years. The mean length of time injecting in the groin was 9.1 years.

\section{Injecting sites}

A total of $75 \%$ of the subjects $(15 / 20)$ injected only on the groin while the others $25 \%(5 / 20)$ injected on the groin along with other sites such as the arm, leg, feet and the neck. A full 95\% (19/20) practiced back-loading when injecting in the groin.

\section{Reasons for choosing the groin}

A clear majority ( $65 \%$ or $13 / 20)$ reported having no other choice as all other sites were exhausted. These were subjects with a long history and aged above 40 and could be considered 'last resort' groin injectors. ${ }^{5}$ However, $30 \%(6 / 19)$ had other choices but preferred the groin and may be categorised as 'convenience' groin injectors. ${ }^{1,6}$

Regardless of whether they injected solely in the groin or otherwise, 95\% (19/20) claimed it delivered euphoria more speedily and more intensely. Many claimed this had become important because the purity level of heroin on the street had declined over the years. Furthermore, the groin was easy to inject on and convenient because of its size, it was a 'sure shot'.?

\section{Dangers of groin injection}

Most groin injectors were well aware of the dangers of injecting in the groin. Some $80 \%(16 / 20)$ knew it could lead to localised skin and soft tissue infec- 
tions; 70\% (14/20) knew it could result in DVT while 15\% (3/20) knew it raised the risks of endocarditis.

Many injectors $(65 \% ; 13 / 20)$ had personally experienced the consequences of injecting wrongly; 35\% (7/20) had at least one experience of suffering extreme ('burning') pain, while 30\% (6/20) had endured continuous itching, swelling and bleeding which required medical attention.

\section{Needle size, access and reuse}

A total of $65 \%(13 / 20)$ of subjects used $0.5 \times 23 \mathrm{~mm}, 25 \mathrm{G}$ while the rest used $0.5 \times 25 \mathrm{~mm}, 25 \mathrm{G}$ needles. Nearly all (90\%) obtained their needles from the needle and syringe exchange programme (NSEP) while two obtained their supply from a pharmacy or medical store. Eleven subjects (55\%) re-used the needles with seven subjects re-using it between two to three times in a week, two re-using between 6-7 times a week and one re-using it between 4-5 times a week and another between 12-13 times a week.

\section{Injecting in a group and needle sharing}

Less than half $(45 \% ; 9 / 20)$ injected with acquaintances; out of which four subjects engaged in needle sharing at a frequency of 2-3 times a week.

\section{Discussion}

Groin and non-groin injectors were no different with respect to most socio-demographic variables, sexual practices and injecting drug use. Both groups therefore displayed the same high risk behaviour. Despite the fact that needles were being obtained from the needle exchange programme, it was being re-used frequently. Sharing of injecting equipment was widespread as was the practice of back loading. Regular condom use was infrequent and having multiple sex partners was quite common.

The length of injecting drug use was positively co-related to groin injection; groin injectors had a longer period of injecting drug use (15.3 years) compared to other injectors (12.2 years). Groin injectors were also significantly more likely to be HCV positive but had the same likelihood of being HIV positive than non-groin injectors. This is not surprising since HCV has greater infectivity relative to HIV.

A previous local study suggested that the declining purity levels of heroin available in the street has led to increased frequency of injections and quicker conversions from smoking to injecting since the latter is a more efficient way of delivering the drug. ${ }^{10}$ Our data further uncovered that it has hastened 
the move from other injecting sites to the groin because it ensured a more intense euphoria within a short time span.

It is disconcerting to note that injectors prefer the groin despite the high degree of awareness of the dangers it poses. Some have reported experiencing complications like collapsed veins, localised skin infections and soft tissue infections but still continue with their practice.

Within this sample of injecting drug users behavioural changes are unlikely to significantly influence the likelihood of injecting in the groin because these are long period injectors. Early prevention efforts and interventions that prevent a drug user from becoming an injecting user will reduce the likelihood of injecting in the groin. Making drug treatment widely available might also slow down the process of conversion to groin injection. Furthermore, although controversial, ensuring purity levels of heroin available to heroin users may also slow down the conversion to injecting drug use and subsequent groin injection. However, providing proper counsel on vein management and injection routines that minimise vein damage is essential.

\section{References}

1. Rhodes T, Briggs D, Kimber J, Jones S, Hollowa G. Crack-heroin speedball injection and its implications for vein care: qualitative study. Addiction. 2007; 102(11):1782-90.

Doi:10.1111/j.1860-0443.2007.01969

PMID: 17784900

2. Senbanjoa R, Strang J. The needle and the damage done: Clinical and behavioural markers of severe femoral vein damage among groin injectors. Drug and Alcohol Dependence. 2011;119:161-65.

Doi:10.1016/j.drugalcdep.2011.06.001

PMID:21719214

3. Miller PG, Lintzeris N, Forzisi L. Is groin injecting an ethical boundary for harm reduction? International Journal of Drug Policy 2008;19:486-91.

Doi:10.1016/j.drugpo.2007.10.001

PMID: 18024001

4. Higgs P, Dwyer R, Duong D, Thach ML, Hellardb M, Power R et al. Heroin-gel capsule cocktails and groin injecting practices among ethnic Vietnamese in Melbourne, Australia. International Journal of 
Drug Policy. 2009; 20: 340-346.

Doi:10.1016/j.drugpo.2008.05.001

PMID: 18835767

5. Darke S, Ross J, Kaye S. Physical injecting sites among injecting drug users in Sydney, Australia. Drug and Alcohol Dependence. 2001;62: 77-82.

Doi:10.1016/S0376-8716(00)00161-7

PMID: 11173170

6. Maliphant J, Scott J. Use of the femoral vein ('groin injecting') by a sample of needle exchange clients in Bristol, UK. Harm Reduction Journal. 2005;2:6

Doi:10.1186/1477-7517-2-6.

7. Rhodes T, Stoneman A, Hope V, Hunt N, Martin A, Judd A. Groin injecting in the context of crack cocaine and homelessness: From 'risk boundary' to 'acceptable risk'? International Journal of Drug Policy. 2006;17:164-70.

Doi:10.1016/j.drugpo.2006.02.011

8. Vicknasingam B, Narayanan S, Navaratnam V. Prevalence rates and risk factors for hepatitis $\mathrm{C}$ among drug users not in treatment in Malaysia. Drug and Alcohol Review. 2009;28:447-54.

Doi: 10.1111/j.1465-3362.2009.00087.x

PMID: 19594801

9. Vicknasingam B, Narayanan S, Navaratnam, V. The relative risk of HIV infection among IDUs not in treatment in Malaysia. AIDS Care. 2009;21(8):984-91.

Doi: $10.1080 / 09540120802657530$.

PMID: 20024754

10. Vicknasingam, B and Navaratnam, V. The use of Rapid Assessment Methodology to Compliment Existing National Assessment and Surveillance Data: A Study among Injecting Drug Users in, Penang, Malaysia. International Journal of Drug Policy. 2008;19:90-93.

Doi:10.1016/j.drugpo.2006.11.004

PMID: 18312823 